\title{
PENGADAAN TANAH UNTUK PEMBANGUNAN JALAN TOL DALAM PERSPEKTIF HAK MENGUASAI NEGARA
}

\author{
Diyan Isnaeni \\ Fakuktas Hukum Universitas Islam Malang \\ Jl. Mayjen Haryono Gg. 10 Kelurahan No.193, Dinoyo, Kec. Lowokwaru, Kota Malang, Jawa \\ Timur 65144 \\ E-mail: diyanfhuim17@gmail.com
}

\begin{abstract}
Problems faced by the government in the implementation of development include the issue of providing land for development itself, including the acquisition of land for toll road construction. because state land which is directly controlled by the state is limited or can be said to be almost nothing anymore. To acquire land for toll road development by the government by freeing people's land, both controlled by customary law, and other rights attached to it. In implementing Law Number 2 of 2012 as a juridical basis, the government carrying out land acquisition for toll road construction often creates problems both juridical and empirical. The legal concept of land acquisition for toll road development in the perspective of the right to control the state, must be returned to the nature of the public interest and the nature of the state's right to control for the greatest prosperity of the people by continuing to create development based on humanitarian principles, meaning that it must continue to prioritize and pay attention to private rights which constitute constitutional rights of the people.
\end{abstract}

Key words: Land Procurement, toll road construction

\begin{abstract}
ABSTRAK
Pemerintah mengalami kesulitan dalam hal pembangunan jalan tol karena tanah negara yang dikuasai langsung oleh negara terbatas atau dapat dikatakan hampir tidak ada lagi. Untuk memperoleh tanah untuk pembangunan jalan tol oleh pemerintah dengan membebaskan tanah milik rakyat, baik yang dikuasai oleh hukum adat, maupun hak-hak lainnya yang melekat diatasnya. Dalam implementasinya Undang-Undang Nomor 2 Tahun 2012 sebagai landasan yuridis pemerintah melaksanakan pengadaan tanah untuk pembangunan jalan tol sering menimbulkan permasalahan baik secara yuridis maupun empiris. Sehingga perlu untuk mengetahui bagaimana konsep hukum pengadaan tanah untuk pembangunan jalan tol dalam perspektif hak menguasai negara. Penelitian dengan yuridis normatif. Konsep hukum pengadaan tanah untuk pembangunan jalan tol dalam perspektif hak menguasai negara, harus dikembalikan pada hakekat kepentingan umum dan hakekat hak menguasai negara yaitu untuk sebesar-besar kemakmuran rakyat dengan tetap menciptakan pembangunan yang berlandaskan asas kemanusiaan artinya harus tetap memprioritaskan dan memperhatikan hak privat yang merupakan hak konstitusional rakyat.
\end{abstract}

Kata Kunci: Pengadaan Tanah, pembangunan jalan tol

\section{PENDAHULUAN}

Pembangunan untuk kepentingan umum dengan tujuan untuk sebesar-besar kemakmuran rakyat menjadi salah satu dasar filosofis bagi pemerintah untuk melaksanakan pengadaan tanah, karena pemerintah memerlukan tanah untuk mewujudkan pembangunan di segala bidang. Tetapi ketersediaan tanah semakin terbatas, sehingga pelaksanaan pengadaan tanah menjadi terhambat, dan berdampak pada 
pelaksanaan pembangunan tidak dapat dilakukan tepat waktu sesuai jadwal yang telah di tetapkan.

Permasalahan yang dihadapi oleh pemerintah dalam pelaksanaan pembangunan diantaranya adalah masalah penyediaan tanah untuk pembangunan itu sendiri, termasuk pengadaan tanah untuk pembangunan jalan tol. Tanah negara yang dikuasai langsung oleh negara terbatas atau dapat dikatakan hampir tidak ada lagi. Satu-satunya jalan yang dapat ditempuh yaitu dengan membebaskan tanah milik rakyat, baik yang dikuasai oleh hukum adat, maupun hak-hak lainnya yang melekat diatasnya.

Pemenuhan kebutuhan akan tanah tersebut diperlukan suatu hak yang memberikan kewenangan besar kepada Pemerintah untuk merencanakan peruntukan dan penggunaan yang bersangkutan guna keperluan usahanya dalam rangka meningkatkan kesejahteraan masyarakat. "Namun dalam kenyataannya pemerintah tidak mampu memenuhi semua penyediaan tanah untuk kebutuhan pembangunan tersebut, sehingga banyak pembangunan yang dilakukan harus dengan cara mengambil dan memanfaatkan tanahtanah rakyat"1

Instrumen hukum yang menjadi dasar landasan bagi negara dalam memperoleh tanah yang telah dimiliki secara privat untuk pembangunan kepentingan umum, dengan cara pengadaan tanah didasarkan pada pasal 33 ayat (3) UUD 1945 sebagai konsep hak menguasai negara dan diatur lebih lanjut kewenangan hak menguasai negara tersebut dalam pasal 2 ayat (3) UUPA. Asas Hak Menguasai Negara diwujudkan dalam Undang-Undang Nomor 2 Tahun 2012 tentang Pengadaan Tanah bagi Pembangunan untuk Kepentingan Umum yang sebelumnya diatur dalam Peraturan Presiden Nomor 65 Tahun 2006. Dalam UU 2/2012 khususnya Pasal 10 huruf $\mathrm{b}$ mengatur tentang jenis kegiatan yang termasuk dalam kepentingan umum yait pembangunan jalan tol.

Penerapan Undang-Undang Nomor 2 Tahun 2012 dalam perkembangannya sering menimbulkan permasalahan baik permasalahan yuridis maupun permasalahan empiris di masyarakat. Permasalahan yuridis dalam pengadaan tanah untuk pembangunan jalan tol yang diatur dalam Undang-Undang Nomor 2 Tahun 2012 adalah adanya kekaburan makna kepentingan umum dan konflik norma antara Undang-Undang Nomor 2 Tahun 2012 dengan Undang-Undang Nomor 38 Tahun 2004 tentang Jalan.

Pengadaan tanah untuk pembangunan jalan tol yang dilaksanakan oleh pemerintah dalam pelaksanaanya diantaranya adalah masalah penyediaan tanah untuk pembangunan itu sendiri, termasuk pengadaan tanah untuk pembangunan jalan tol. Tanah negara yang

1 Ketut Wikantika, 9 April 2007, Bank Tanah Pengendali Harga Tanah, tersedia dalam http://wikantika.wordpress.com/2007/04/09/bank-tanah-pengendali-harga-tanah/, diakses tanggal 10 Mei 2017. 
dikuasai langsung oleh negara terbatas atau dapat dikatakan hampir tidak ada lagi. Satusatunya jalan yang dapat ditempuh yaitu dengan membebaskan tanah milik rakyat, baik yang dikuasai oleh hukum adat, maupun hak-hak lainnya yang melekat diatasnya.

Pengadaan tanah adalah kegiatan menyediakan tanah dengan cara memberi ganti kerugian yang layak dan adil kepada pihak yang berhak sebagaimana diatur dalam pasal 1 angka (2) Undang-Undang Nomor 2 Tahun 2012. Undang-Undang Nomor 38 Tahun 2004 tentang Jalan pasal 1 angka 7 dan 8 menentukan bahwa jalan tol adalah jalan umum yang merupakan bagian sistem jaringan jalan dan sebagai jalan nasional yang penggunaannya diwajibkan membayar tol. Sedangkan yang dimaksud dengan tol adalah sejumlah uang tertentu yang dibayarkan untuk penggunaan jalan tol.

Pasal 2 ayat (1) Peraturan Pemerintah Nomor 15 Tahun 2005 tentang Jalan Tol disebutkan bahwa penyelenggaraan jalan tol dimaksudkan untuk mewujudkan pemerataan pembangunan dan hasil-hasilnya serta keseimbangan dalam pengembangan wilayah dengan memperhatikan keadilan, yang dapat dicapai dengan membina jaringan jalan yang dananya berasal dari pengguna jalan. Tujuan penyelenggaraan jalan tol meningkatkan efisiensi pelayanan jasa dan distribusi barang guna peningkatan pertumbuhan ekonomi terutama diwilayah yang tinggi tingkat perkembangannya.

Berdasarkan latar belakang dan kompleksitas permasalahan pengadaan tanah untuk pembangunan jalan tol tersebut, yang menjadi permasalahan dalam tulisan ini adalah bagaimana konsep hukum pengadaan tanah untuk pembangunan jalan tol dalam perspektif hak menguasai negara? Menggunakan metode penelitian yuridis normatif dengan pendekatan statue approach dan conceptual approach.

\section{PEMBAHASAN}

\section{Konsep Hak Menguasai Negara}

Konsep dasar hak menguasai tanah oleh negara termuat dalam Pasal 33 Ayat (3) UUD 1945 yang berbunyi: "Bumi dan air dan kekayaan alam yang terkandung di dalamnya dikuasai oleh negara dan dipergunakan untuk sebesar-besar kemakmuran rakyat." Dari ketentuan pasal 33 ayat (3) UUD NRI 1945 hubungan antara negara dengan bumi, air, dan kekayaan alam yang terkandung didalamnya dikuasai oleh negara dan digunakan untuk sebesar-besar kemakmuran rakyat. Hal ini berarti bahwa dengan dikuasainya bumi, air, dan kekayaan alam oleh negara, pemerataan atas hasil-hasil pengelolaan terhadap bumi, air, dan kekayaan alam ini akan dapat tercapai. ${ }^{2}$ Tujuan diberikannya hak menguasai kepada negara ialah untuk mencapai sebesarbesar kemakmuran rakyat, dalam arti:" Kebahagiaan, kesejahteraan dan

\footnotetext{
2 Mansour Fakih, (2003), Landreform di Desa, Cetakan I. Maret, Yogyakarta: Read Book, hlm. 34-35.
} 
kemerdekaan dalam masyarakat dan negara hukum Indonesia yang merdeka, berdaulat, adil dan makmur."’3

Hak menguasai dari negara atas tanah bersumber pada Hak Bangsa Indonesia atas tanah, yang hakikatnya merupakan pelaksanaan tugas kewenangan bangsa yang mempunyai unsur publik. Tugas mengelola seluruh tanah bersama tidak mungkin dilaksanakan sendiri oleh seluruh Bangsa Indonesia, maka dalam penyelenggaraannya, Bangsa Indonesia sebagai pemegang hak dan pengemban amanat tersebut, pada tingkatan tertinggi dilaksanakan oleh Negara Republik Indoensia sebagai organisasi kekuasaan seluruh rakyat (Pasal 2 ayat (1) UUPA).

Wewenang penguasaan oleh negara meliputi bumi, air dan ruang angkasa di wilayah Negara Republik Indonesia, baik yang: “(1) di atasnya sudah ada hak-hak perorangan/keluarga, apapun nama hak itu; (2) di atasnya masih ada hak ulayat dan hakhak semacam itu, apapun nama hak tersebut; dan (3) di atasnya tidak ada hak-hak pemegang hak-hak tersebut, (misalnya bekas tanah Swapraja, tanah bekas hak-hak Barat, tanah tak bertuan, hutan negara dan lain-lain sebagainya ${ }^{4}$. Dengan demikian, penguasaan oleh negara yang disebut dengan HMN merupakan hubungan hukum antara negara sebagai subyek dengan sumber daya agraria sebagai obyek. Hubungan hukum tersebut melahirkan hak'untuk menguasai sumber daya agraria dan sekaligus kewajiban bagi negara dalam penggunaan SDA tersebut yaitu untuk sebesar-besar kemakmuran rakyat.

\section{Konsep Pengadaan Tanah menurut Undang-Undang Nomor 2 Tahun 2012}

Secara konseptual pengadaan tanah bagi pembangunan untuk kepentingan umum yang diatur dalam Undang-Undang Nomor 2 Tahun 2012 terkait dengan konsep mekanisme pencapaian tujuan negara, yang terdapat dalam suatu teori negara kesejahteraan (welfare state). Tujuan pengadaan tanah untuk kepentingan umum adalah menyediakan tanah bagi pelaksanaan pembangunan guna meningkatkan kesejahteraan dan kemakmuran bangsa, negara, dan masyarakat dengan tetap menjamin kepentingan hukum yang berhak. Pihak yang berhak wajib melepaskan tanahnya pada saat pelaksanaan pengadaan tanah untuk kepentingan umum setelah pemberian ganti kerugian yang layak dan adil atau berdasarkan putusan pengadilan yang telah memperoleh kekuatan hukum yang tetap. Tanah yang selanjutnya dibangun sesuatu untuk kepentingan umum akan menjadi milik Pemerintah/Pemerintah Daerah atau milik BUMN apabila dipergunakanan untuk kepentingannya.

\footnotetext{
3 Iman Soetiknjo, (1994), Politik Agraria Nasional: Hubungan Manusia dengan Tanah yang Berdasarkan Pancasila, Yogyakarta; Gadjahmada University Press, hlm. 16.

4 Ibid, hlm. 52-53.
} 
Ganti Kerugian sebagaimana dimaksud dalam Pasal 1 angka 10 Undang-Undang Nomor 2 Tahun 2012 adalah penggantian yang layak dan adil kepada pihak yang berhak dalam proses pengadaan tanah. Dengan demikian pengadaan tanah merupakan setiap kegiatan untuk mendapatkan tanah dengan cara memberi ganti rugi kepada yang melepaskan hak atau menyerahkan tanah, bangunan, tanaman, dan benda-benda yang berkaitan dengan tanah atau dengan pencabutan hak atas tanah. Objek pengadaan tanah adalah tanah, ruang atas tanah, dan bawah tanah, bangunan, tanaman, benda yang berkaitan dengan tanah atau lainnya yang dapat dinilai.

Konsep Hukum Pengadaan Tanah Untuk Pembangunan Jalan Tol Dalam Perspektif

\section{Hak Menguasai Negara}

Secara etimologis kata konsep berasal dari bahasa latin "conceptum" yang artinya sesuatu yang bisa dipahami. Pengertian konsep lainnya adalah serangkaian pernyataan, idea atau gagasan yang saling terkait tentang berbagai kejadian atau peristiwa dan menjadi dasar atau petunjuk dalam melakukan penelitian. Setiap ilmu selalu terbentuk berbagai konsep yang diungkapkan dengan suatu istilah berupa satu atau beberapa perkataan. Biasanya dipilih perkataan dari bahasa sehari-hari, namun tidak jarang dipilih kata-kata dari bahasa yang sudah tidak digunakan dalam percakapan sehari-hari atau diciptakan perkataan baru.
Dirumuskan atau dijadikan pengertian atau konsep hukum maka perumusan dan ruang lingkupnya menjadi jelas dan tegas. Konsep hukum sebenarnya merupakan pengertian ilmiah dan mempunyai batas tegas sehingga berbeda dengan konsep keseharian. Apabila konsep hukum tersebut berasal dari pengertian sehari-hari, misalnya yang digunakan dalam undang-undang atau dalam putusan hakim, maka pengertian atau konsep tersebut akan memperoleh batasan yang tegas.

Pembahasan mengenai konsep hukum pengadaan tanah untuk pembangunan jalan tol dimaksudkan untuk mengetahui dasar filosofi yang mendasari konsep hukum pengaturan pengadaan tanah untuk pembangunan jalan tol. Pengaturan konsep hukum pengadaan tanah untuk pembangunan jalan tol ini diperlukan dan digunakan untuk memahami suatu aturan hukum atau sistem aturan hukum terutama untuk memudahkan penataan, pemahaman dan penggunaan atas bahanbahan yang dipelajari dalam pengaturan pengadaan tanah untuk pembangunan jalan tol sehingga tersusun bangunan pengetahuan tentang pengadaan tanah untuk pembangunan jalan tol yang mewujudkan suatu sistem yang secara rasional dapat dipelajari dan dipahami.

Konsep hukum dalam pengaturan pengadaan tanah untuk pembangunan jalan tol ini sangat penting, terutama didalam melakukan suatu argumentasi hukum. Apabila dalam suatu masalah atau kasus yang sedang dihadapi hakim belum ada peraturan 
hukumnya maka dapat dilakukan usaha pembentukan hukum.

Hak menguasai negara menurut UUD NRI 1945 harus dilihat dalam konteks hak dan kewajiban negara sebagai pemilik kekuasaan yang mengemban tugas menciptakan kesejahteraan rakyat. Kedudukan negara sebagai badan penguasa pemilik kekuasaan itu adalah pengejawantahan dari faham pola hubungan antara perseorangan dengan masyarakat dalam konsepsi hukum adat yang kristalisasi nilai-nilainya terumuskan dalam Pembukaan UUD NRI 1945, sehingga hak menguasai negara mengandung didalamnya untuk melaksanakan hak dan kewajibannya yang melahirkan kekuasaan, wewenang bahkan daya paksa.

Setelah diteliti dan dianalisis ditemukan bahwa konsep hukum pengadaan tanah untuk pembangunan jalan tol dalam perspektif hak menguasai negara yang diatur dalam UndangUndang Nomor 2 Tahun 2012 secara filosofis belum sesuai dengan konsep Hak Menguasai Negara yaitu untuk sebesar-besar kemakmuran rakyat. Hal ini dikarenakan pelaksanaan pengadaan tanah untuk pembangunan jalan tol belum mensejahterakan masyarakat yang tanahnya diambil untuk pembangunan jalan tol. Secara normatif konsep hukum pengadaan Tanah untuk pembangunan jalan tol yang diatur dalam Undang-Undang Nomor 2 Tahun 2012 dalam perspektif hak menguasai negara ditemukan adanya:

a) Kekaburan norma (vage normen) tentang makna kepentingan umum

Terjadinya dinamika politik hukum dan pembangunan dalam rangka meningkatkan pertumbuhan ekonomi menyebabkan terjadi pula perubahan-perubahan makna kepentingan umum dalam peraturan perundang-undangan yang pernah berlaku tentang pengadaan tanah untuk kepentingan umum, hal ini dikarenakan ada ketidak jelasan atau kekaburan makna kepentingan umum.

Apabila terjadi kekaburan makna tentang suatu norma maka didasarkan pendapat Dworkin dapat dilakukan penafsiran atau interpretasi karena menurutnya dalam hal terjadi ketidakjelasan norma hukum, pelaksana hukum menggunakan diskresi yang lemah (aweak discretion), yaitu menggunakan interpretasi dengan merujuk pada prinsipprinsip atau asas-asas hukum terkait, setelah itu baru merumuskan norma hukumnya. $^{5}$ Alasan digunakannya pemikiran Dworkin sebagai acuan untuk menafsirkan kekaburan norma tentang makna kepentingan umum dalam pembangunan jalan tol, hal ini disebabkan

\footnotetext{
5 Slamet Suhartono, Hukum Positif dan probematik Penerapan dan Solusi Teoritikmya DiH: Jurnal Ilmu Hukum Volume 15 Nomor 2 Agustus 2019 - Januari 2020, hlm. 205
} 
bahwa menurut Dworkin norma selalu bersumber dari moralitas, hukum berakar pada prinsip-prinsip moralitas, artinya hukum merupakan bagian dari satu sistem ajaran moral, selain itu hukum merupakan penjabaran dari prinsip-prinsip moral umum yang berlaku secara universal dan mengatasi berbagai kebudayaan khususnya prinsip keadilan, sehingga hakim dalam menafsikran harus mendasarkan pada nilai-nilai moral dan cita keadilan yang berada di balik norma samar tersebut ${ }^{6}$, dalam hal ini makna kepentingan umum.

Dengan menemukan difinisi kepentingan umum yang tepat, kemudian ditentukan jenis-jenis atau daftar kegiatan kepentingan umum maka kepentingan umum dalam pengadaan tanah mempunyai kepastian hukum dan rakyat akan terlindungi hak-haknya. Perumusan makna kepentingan umum secara jelas dirasa amat penting bagi pembentuk undangundang agar terdapat keatuan pemahaman mengenai makna kepentingan umm baik bagi pemerintah maupunn masyarakat.

b) Konflik norma antara Undang-Undang Nomor 2 Tahun 2012 dengan UndangUndang Nomor 20 Tahun 1961

Ketidaksesuaian konsep pengadaan tanah untuk pembangunan jalan tol dengan konsep hak menguasai negara mengakibatkan juga terjadinya konflik norma yang terkait dengan kriteria dan jenis kepentingan umum untuk pembangunan jalan tol. Konflik norma secara horizontal ini terjadi antara UndangUndang Nomor 20 Tahun 1961 tentang Pencabutan hak atas tanah, dan UndangUndang Nomor 2 Tahun 2012 pembangunan untuk kepentingan umum. Kedua peraturan tersebut sama-sama merupakan dasar yuridis pengambilan tanah oleh pemerintah untuk kepentingan umum artinya walaupun sudah disahkannya Undang-Undang Nomor 2 Tahun 2012 yang mengatur tentang perolehan tanah yang dilakukan pemerintah untuk keperluan kepentingan umum.

Terhadap konflik norma secara horizontal dalam pengaturan tentang kriteria dan jenis kepentingan umum khususnya pembangunan jalan tol yang diatur dalam Undang-Undang Nomor 20 Tahun 1961 tentang Pencabutan Hak Atas Tanah dan benda-benda diatasnya dengan Undang-Undang Nomor 2 Tahun 2012, maka bisa diselesaikan dengan metode atau asas preferensi sebagaimana pendapat dari Gert Frederict Malt. Menurut Malt ada tiga metode yang digunakan untuk menyelesaikan apabila terjadi konflik

6 Zafeer, Jurisprudenze: An Outline (International Law Book Services, 1994). 
norma sebagaimana telah diuraikan sebelumnya yakni:

a) the lex posterior principle: lex posterior derogate legi priori, i.e: a later provisions overrules an earlier one;

b) the lex specialis principles: lex spesialis derogate legi generali, i.e.: a more special provision overrules a general one;

c) the lex superior principle: lex superior derogat legi inferior, i.e.: provision with higher rank overrules a provision with lower rank $^{7}$

Terhadap konflik norma secara horizontal antara Undang-Undang Nomor 20 Tahun 1961 dengan Undang-Undang Nomor 2 Tahun 2012, lebih tepat menggunakan asas lex posterior derogate legi priori. Sehingga dalam hal pengaturan mengenai kriteria dan jenis kegiatan yang termasuk kepentingan umum khususnya untuk pembangunan jalan tol, akan digunakan Undang-Undang Nomor 2 Tahun 2012 sebagai undang-undang yang terbaru sebagai dasar yuridis dalam pengadaan tanah untuk pembangunan jalan tol

c) Konflik Norma antara Undang-Undang Nomor 38 Tahun 2004 dengan UndangUndang Nomor 2 Tahun 2012 berkaitan dengan pengaturan pemberian ganti rugi
Terjadinya konflik norma horizontal antara Undang-Undang Nomor 38 Tahun 2004 tentang Jalan dengan UndangUndang Nomor 2 Tahun 2012 berkaitan dengan pengaturan pemberian ganti kerugian terutama apabila para pihak tidak mencapai kesepakatan mengenai lokasi pembangunan jalan tol dan pemberian ganti kerugian.

Pasal 59 Undang-Undang Nomor 38 Tahun 2004, yang isinya dijelaskan bahwa:

1) Apabila kesepakatan tidak tercapai dan lokasi pembangunan tidak dapat dipindahkan, dilakukan pencabutan hak atas tanah sesuai dengan peraturan perundang-undangan dibidang pertanahan;

2) Pelaksanaan pembangunan jalan dapat dimulai pada bidang tanah yang telah diberi ganti rugi atau telah dicabut hak atas tanahnya

Peraturan di bidang pertanahan disini berarti didasarkan pada Undang-Undang Nomor 20 Tahun 1961 tentang Pencabutan hak atas tanah. Sedangkan dalam UndangUndang Nomor 2 Tahun 2012 sebagai hukum positif pelaksanaan pengadaan tanah untuk pembangunan jalan tol, terutama dalam hal tidak tercapai kesepakatan mengenai rencana lokasi pembangunan jalan tol, bisa dilakukan upaya hukum dengan mengajukan keberatan ke Gubernur, sebagaimana diatur

7 Gert-Fredrik Malt, "Methods for the solution of Con $\square$ ict between Rule in a sistem of Positive Law" dalam Bob Brouwer, et.al., Editor, Coherence and Co $\square$ ict in Law, Procceedings of the 3rd Benelux-Scandinavian Symposium in Legal Theory. hlm. 21148 Gert-Fredrik Malt, Op.Cit., hlm..208 
dalam Pasal 21 Undang-Undang Nomor 2

Tahun 2012 dan apabila keputusan

Gubernur yang isinya menolak laporan keberatan tentang lokasi pembangunan jalan tol maka dalam pasal 23 disebutkan bahwa akan dilakukan upaya hukum dengan mengajukan gugatan ke Pengadilan Tata Usaha Negara. Apabila para pihak keberatan terhadap putusan Pengadilan Tata Usaha Negara dapat mengajukan gugatan kasasi ke Mahkamah Agung dan putusan pengadilan yang telah mempunyai kekuatan hukum tetap menjadi dasar diteruskan atau tidaknya pengadaan tanah untuk kepentingan umum.

Mengenai tidak tercapai kesepakatan dalam hal pemberian ganti kerugian. Undang-UndangNomor 2 Tahun 2012 diatur dalam pasal 38 ayat (1) dan pasal 42 ayat (1).

Pasal 38 ayat (1) Undang-Undang Nomor 2 Tahun 2012, menyebutkan bahwa

"Dalam hal tidak tercapai kesepakatan mengenai bentuk dan/atau besarnya ganti kerugian, pihak yang berhak dapat mengajukan keberatan kepada pengadilan negeri setempat dalam waktu paling lama 14 (empat belas) hari kerja setelah musyawarah penetapan ganti kerugian sebagaimana dimaksud dalam pasal 37 ayat (1)".

Pasal 42 (1) Undang-Undang Nomor 2 Tahun 2012 :
"Dalam hal Pihak yang Berhak menolak bentuk dan/ atau besarmya Ganti Kerugian berdasarkan hasil musyawarah sebagaimana dimaksud dalam Pasal 37, atau putusan Pengadilan Negeri/Mahkamah Agung sebagaimana dimaksud dalam Pasal 38, Ganti Kerugian dititipkan di pengadilan negeri setempat"

Berdasarkan uraian ketentuan-ketentuan tersebut dalam hal pengaturan tentang tidak tercapainya kesepakatan rencana lokasi pembangunan untuk kepentingan umum termasuk jalan tol dan tidak tercapai kesepakatan mengenai pemberian ganti kerugian, ada ke tidak sesuaian antara Undang-Undang Nomor 38 Tahum 2004 yaitu dengan dilakukan pencabutan hak atas tanah dan Undang-Undang Nomor 2 Tahun 2012 dilakukan dengan upaya-upaya hukum mulai dari ke Gubernur, ke Peradilan Tata Usaha Negara dan Mahkamah Agung untuk keberatan terhadap rencana lokasi pembangunan kepentingan umum dan ke Pengadilan Negeri, ke Mahkamah Agung dan dilakukan Konsinyasi atau penitipan uang ke Pengadilan Negeri apabila tidak tercapai kesepakatan mengenai pemberian ganti kerugian.

Penyelesaian terhadap konflik norma antara Undang-Undang Nomor 38 Tahun 2004 tentang Jalan, khususnya pasal 59 dengan UU Nomor 2 Tahun 2012 pasal 22 ayat (2) dan pasal 42 (1) yang berkaitan dengan tidak tercapainya kesepakatan mengenai besarnya ganti kerugian tersebut, 
maka dapat diselesaikan dengan menggunakan asas preferensi sebagaimana pendapat Gert Frederict Malt yang telah diuraikan sebelumnya.dengan menggunakan asas lex specialis derogat lex generali.

Jika terjadi demikian maka peraturan perundang-undangan yang bersifat khusus yaitu Undang-Undang Nomor 2 Tahun 2012 akan mengesampingkan peraturan perundang-undangan yang bersifat umum dalam hal ini Undang-Undang Nomor 38 Tahun 2004. Artinya apabila terjadi sengketa antara pemerintah yang memerlukan tanah untuk pembangunan jalan tol dengan masyarakat yang tanahnya diambil untuk kepentingan pembangunan jalan tol karena tidak tercapai kata sepakat pemberian ganti kerugian maka penyelesaiannya akan didasarkan Undang-Undang Nomor 2 Tahun 2012.

Meskipun tanah yang dimiliki masyarakat melekat asas fungsi sosial, yang harus memberikan tanahnya untuk kepentingan bersama, namun tetap memperhatikan hak konstitusional masyarakat itu sendiri terkait dengan kepemilikan tanah. Dengan menganalisis konsep hukum pengadaan tanah untuk pembangunan jalan tol dalam UndangUndang Nomor 2 Tahun 2012 maka konsep hukum pengadaan tanah untuk pembangunan jalan tol dalam perspetikf hak menguasai negara, dalam perkembangan hukum agraria yang akan datang, harus dikembalikan pada hakekat kepentingan umum dan hakekat hak kemakmuran rakyat dengan tetap menciptakan pembangunan yang berlandaskan asas kemanusiaan artinya harus tetap memprioritaskan dan memperhatikan hak privat yang merupakan hak konstitusional rakyat, karena konstitusi telah memberikan jaminan dan perlindungan terhadap hak milik pribadi warganya termasuk hak milik atas tanah sebagaimana diatur dalam UUD NRI 1945 pasal 28H ayat (4) Negara memiliki kedudukan dominan dalam mewujudkan kesejahteraan masyarakat. Kedudukan tersebut didasarkan pada kewenangan yang secara konstitusional adalah sah. Dengan demikian sebagai pihak yang memiliki bergaining position, negara ikut campur tangan menentukan arah kebijakan guna mengangkat harkat dan martabat bangsa dan negara.

Konsep hukum pengadaan tanah dalam perspektif hak menguasai negara selanjutnya adalah bahwa pengadaan tanah untuk pembangunan jalan tol harus menjadi tanggungjawab negara, dan tidak harus menjadi tanggungjawab swasta. Hal ini dikarenakan negara ditempatkan sebagai pembawa perubahan sekaligus pengatur, perencana dan pengelola bumi air dan kekayaan alam yang terkandung didalamnya baik dalam membuat rencana strategis, untuk pembangunan kawasan strategis dan proyek strategis nasional yang termasuk didalamnya adalah pembangunan infrastruktur jalan tol. 
sebagaimana diatur pasal 34 ayat (3) UUD NRI 1945 dan pasal 1 angka (6) Undangundang Nomor 2 Tahun 2012.

Disamping itu konsep hukum pengadaan tanah untuk pembangunan jalan tol dalam perspektif hak menguasai negara maka dalam pembuatan perencanaan pengadaan tanah untuk pembangunan jalan tol harus didasarkan pada kerangka sosialisme Indonesia yang didasarkan pada tatanan masyarakat yang adil dan makmur berdasarkan Pancasila sebagaimana diatur dalam pasal 5 dan pasal 14 UUPA.

\section{KESIMPULAN DAN SARAN}

\section{Kesimpulan}

Konsep hukum pengadaan tanah untuk pembangunan jalan tol dalam perspektif hak menguasai negara, harus dikembalikan pada hakekat kepentingan umum dan hakekat hak menguasai negara yaitu untuk sebesar-besar kemakmuran rakyat dengan tetap yaitu menciptakan pembangunan yang berlandaskan asas kemanusiaan artinya harus tetap memprioritaskan dan memperhatikan hak privat yang merupakan hak konstitusional rakyat, karena konstitusi telah memberikan jaminan dan perlindungan terhadap hak milik pribadi warganya termasuk hak milik atas tanah sebagaimana diatur dalam UUD NRI 1945 pasal $28 \mathrm{H}$ ayat (4)

Pengadaan tanah untuk pembangunan jalan tol harus menjadi tanggungjawab swasta, karena negara adalah pengatur, perencana dan pengelola/pengurus bumi, air dan kekayaan alam yang terkandung didalamnya baik dalam membuat rencana strategis, untuk membangunan kawasan strategis dan proyek strategis nasional yang termasuk didalamnya adalah pembangunan infrastruktur jalan tol. sebagaimana diatur pasal 34 ayat (3) UUD NRI 1945 dan pasal 1 angka (6) Undang-undang Nomor 2 Tahun 2012.

\section{Saran}

1. Pemerintah melakukan harmonisasi hukum peraturan-peraturan yang berkaitan dengan pengadaan tanah untuk pembangunan jalan tol dengan tujuan memperbaiki konsep hukum pengadaan tanah untuk pembangunan jalan tol dalam perspektif hak menguasai negara agar tidak terjadi konflik norma.

2. Pemerintah melakukan revisi terhadap Undang-Undang Nomor 2 Tahun 2012, dan untuk masyarakat (orang perorangan atau Badan hukum publik atau DPR ) bisa mengajukan uji materiil ke Mahkamah Konstitusi atas pasal 11ayat (1) dan pasal 14 ayat (1) Undang-Undang Nomor 2 Tahun 2012.

\section{DAFTAR PUSTAKA}

\section{Peraturan Perundang-undangan}

Undang-Undang Dasar Negara Republik Indonesia 1945

Undang-Undang Nomor 5 Tahun 1960 tentang Peraturan Dasar Pokok Agraria

Undang-Undang Nomor 2 Tahun 2012 tentang Pengadaan tanah Bagi Pembangunan Untuk Kepentingan Umum

\section{Buku}


Gert-Fredrik Malt, "Methods for the solution of Confict between Rule in a sistem of Positive Law" dalam Bob Brouwer, et.al., Editor, Coherence and Co $\square$ ict in Law, Procceedings of the 3rd BeneluxScandinavian Symposium in Legal Theory.

Iman Sutiknyo, 1990, Politik Agraria Nasional. Hubungan Manusia dengan Tanah yang berdasarkan Pancasila, Yogyakarta; Gadjah Mada Univeresity Press.

Winahyu Erwiningsih, 2009, Hak Menguasai Negara Atas Tanah, Yogyakarta; Total Media.

\section{Jurnal}

Muchsan, 1997, "Perbuatan Pemerintah dalam Memperoleh Tanah Untuk Kepentingan Umum”, Disertasi, Program Pascasarjana UGM, Yokyakarta: PPS UGM.

Slamet Suhartono, Hukum Positif dan probematik Penerapan dan Solusi Teoritikmya DiH: Jurnal Ilmu Hukum Volume 15 Nomor 2 Agustus 2019 Januari 2020.

Zafeer, 1994, Jurisprudenze: An Outline International Law Book Services.

\section{Internet}

Ketut Wikantika, 9 April 2007, Bank Tanah Pengendali Harga Tanah, tersedia dalam http://wikantika.wordpress.com/2007/0 4/09/bank-tanah- pengendali-hargatanah/, diakses tanggal 10 Mei 2019. 